\title{
PERLINDUNGAN HUKUM BAGI DOKTER GIGI DALAM MELAKUKAN PELAYANAN KESEHATAN DI PUSKESMAS
}

\author{
Dedy Kuswandi \\ Program Studi Magister Ilmu Hukum \\ Pascasarjana Universitas Islam Bandung \\ Email : dkosny868@gmail.com
}

\begin{abstract}
Abstrak - Puskesmas adalah sarana pelayanan kesehatan dasar di Indonesia. Salah satu pelayanan kesehatan di Puskesmas yaitu pelayanan kesehatan gigi dan mulut. Hubungan hukum antara dokter gigi dan pasien di Puskesmas merupakan suatu perhubungan hukum yang lahir atas dasar perjanjian terapeutik. Akan tetapi, seringkali pasien menuntut dokter karena penyakitnya tidak berhasil disembuhkan, padahal dalam kontrak terapeutik objek perjanjian adalah usaha atau upaya sebaikbaiknya dari dokter untuk menyembuhkan dan bukan sembuh atau tidak sembuhnya pasien. Penulisan ini bertujuan untuk mengetahui perlindungan hukum bagi dokter gigi dalam melakukan pelayanan kesehatan terhadap pasien di Puskesmas. Metode penelitian yang digunakan yaitu yuridis normatif yang bersifat deskriptif, menggunakan data sekunder melalui studi kepustakaan dan studi lapangan, yang di analisis secara kualitatif. Hasil penelitian menunjukan bahwa perlindungan hukum bagi dokter gigi dalam melakukan pelayanan kesehatan di Puskesmas merupakan hak yang diberikan oleh hukum sepanjang telah melakukan tugasnya sesuai dengan standar profesi dan standar prosedur operasional.
\end{abstract}

Kata Kunci : Perlindungan Hukum, Dokter Gigi, Puskesmas

Abstract - Puskesmas is a basic health service facility in Indonesia. One of the health services at the Puskesmas is dental and oral health services. The legal relationship between the dentist and the patient at the Puskesmas is a legal relationship born based on a therapeutic agreement. However, patients often sue doctors because the disease was not successfully cured, even though in the therapeutic contract the object of the agreement is the best effort or effort from the doctor to cure and not cure or not cure the patient. This writing aims to determine the legal protection for dentists in providing health services to patients at the Puskesmas. The research method used is normative juridical descriptive, using secondary data through literature studies and field studies, which are analyzed qualitatively. The results showed that the legal protection for dentists in performing health services in Puskesmas is a right granted by law as long as they have performed their duties in accordance with professional standards and operational procedure standards.

\section{Keyword : Legal Protection, Dentist, Public Health Center}

\section{A. PENDAHULUAN}

Puskesmas adalah sarana pelayanan kesehatan dasar yang amat penting di Indonesia yang merupakan unit strategis dalam mendukung terwujudnya perubahan status kesehatan masyarakat menuju peningkatan derajat kesehatan yang optimal. Untuk mewujudkan derajat kesehatan yang optimal tentu diperlukan upaya pembangunan sistem pelayanan 
kesehatan dasar yang mampu memenuhi kebutuhan-kebutuhan masyarakat dari pelayanan kesehatan dasar tersebut (Hadi Mahmud, Suparwi, 2015 : 202-203). Cakupan pelayanan yang diterima di Puskesmas yaitu rawat jalan tingkat pertama, pelayanan kesehatan gigi dan mulut, rawat inap tingkat pertama dan pelayanan darah sesuai indikasi medis.

Kualitas pelayanan kesehatan di Puskesmas merupakan salah satu faktor yang mendorong kepuasan pasien terhadap pelayanan kesehatan yang diterimanya. Kepuasan pasien terhadap pelayanan kesehatan gigi dan mulut adalah perbandingan antara persepsi terhadap pelayanan yang diterima dengan harapan sebelum mendapatkan pelayanan. Pelayanan dikatakan telah memberikan suatu kualitas yang luar biasa dan juga akan menimbulkan kepuasan yang tinggi apabila harapan pasien sebelum mendapatkan pelayanan terpenuhi (Mariane Sembel, Henry Opod, Bernart S. P. Hutagalung, 2014).

Pada pelayanan kesehatan gigi dan mulut di Puskesmas, kemampuan dokter gigi dalam pelayanan kesehatan gigi dan mulut, merupakan modal dasar peningkatan derajat kesehatan gigi dan mulut masyarakat. Pelayanan kesehatan gigi dan mulut juga harus didukung oleh sarana dan prasarana yang memadai sehingga hasil yang diberikan menjadi maksimal atau memenuhi Standar Pelayanan Minimal sebagaimana yang diatur dalam Peraturan Menteri Kesehatan Nomor 75 Tahun 2014 tentang Pusat Kesehatan Masyarakat.

Dalam hal pelayanan kesehatan, hubungan antara dokter dengan pasien merupakan hubungan keperdataan, dimana pasien datang untuk disembuhkan penyakitnya dan dokter berjanji akan menyembuhkan penyakit pasien. Hubungan keperdataan adalah hubungan hukum yang dilakukan oleh pihak-pihak yang berada dalam kedudukan sederajat, setidak-tidaknya pada saat para pihak akan memasuki hubungan hukum tertentu (Syahrul Machmud, 2008 : 44).

Secara yuridis, timbulnya hubungan antara dokter dan pasien berdasarkan dua hal, yaitu perjanjian (ius contractual) atau yang disebut dengan transaksi terapeutik, hubungan ini sifatnya pribadi antara dokter dengan pasiennya karena didasarkan pada kepercayaan, dan undang-undang (zaakwarneming).

Dikatakan zaakwarneming atau perwakilan sukarela, apabila pasien dalam keadaan tidak sadar sehingga dokter tidak mungkin memberikan informasi, maka dokter dapat bertindak atau melakukan upaya medis tanpa seizin pasien sebagai tindakan berdasarkan perwakilan sukarela atau menurut ketentuan Pasal 1354 Kitab Undang-Undang Hukum Perdata (Agus 
Budianto, at., al., 2010 : 88). Hubungan antara dokter dengan pasien yang didasarkan atas perjanjian atau transaksi terapeutik, yaitu perjanjian dimana dokter berusaha semaksimal mungkin menyembuhkan pasien (Syahrul Machmud, 2008 : 44).

Peraturan Menteri Kesehatan Nomor 75 Tahun 2014 tentang Pusat Kesehatan Masyarakat telah menetapkan berbagai standar dan pedoman yang terkait dengan pelayanan kesehatan pada suatu Puskesmas sebagai acuan untuk dapat memberikan pelayanan kesehatan yang optimal kepada masyarakat. Namun dalam prakteknya, masih terdapat Puskemas yang belum memenuhi ketentuan-ketentuan yang ditetapkan dalam Permenkes Puskesmas tersebut, salah satunya yaitu Puskesmas Sarijadi di Kota Bandung.

Puskesmas Sarijadi, secara struktural berada di bawah Unit Pelayanan Terpadu (UPT) Puskesmas Sukarasa sebagai Puskesmas jejaring hingga bulan Januari tahun 2018. Pada tanggal 6 Februari 2018 berdasarkan penetapan Surat Keputusan Wali Kota Bandung Nomor 199 Tahun 2018, berubah statusnya menjadi UPT Puskesmas Sarijadi. Puskesmas Sarijadi adalah salah satu Puskesmas perkotaan dengan pelayanan kesehatan bermutu yang memenuhi atau melebihi harapan pelanggan serta memberikan pelayanan yang sesuai dengan Standart Operating
Procedure (SOP) pelayanan kesehatan untuk mewujudkan masyarakat Sarijadi yang sehat dan mandiri tahun 2020. Dalam pelayanannya, Puskesmas Sarijadi hanya melayani pemeriksaan kesehatan Rawat Jalan dan tidak melayani Rawat Inap. Salah satu pelayanan kesehatan yang tersedia yaitu pelayanan kesehatan rawat jalan gigi dan mulut.

Berdasarkan hasil penelitian, permasalahan yang terjadi di Puskesmas Sarijadi adalah sumber daya manusia yang sangat terbatas, penempatan tenaga dokter yang tidak merata oleh pemerintah serta masih belum lengkapnya sarana dan prasana lainnya seperti peralatan dan perlengkapan di poli gigi yang belum memenuhi standar yang ditetapkan. Dengan adanya program BPJS, pasien yang banyak tidak akan memberikan pelayanan yang optimal apabila tidak didukung oleh ketersediaan tenaga yang memadai, sementara Puskesmas dituntut untuk melakukan pelayanan secara optimal karena Puskesmas dianggap sudah mendapatkan kapitasi, begitu pula apabila jumlah pasien banyak sementara ketersediaan tenaga kesehatan terbatas akan berdampak kepada kesehatan dokternya sebagaimana secara etika profesi dokter perlu menjaga kesehatannya karena demi keselamatan pasien.

Disisi lain, seringkali terdengar pasien menuntut dokter karena 
penyakitnya tidak berhasil disembuhkan, padahal dalam kontrak terapeutik, objek perjanjian adalah usaha atau upaya sebaikbaiknya dari dokter untuk menyembuhkan (inspanning verbitenis) dan sama sekali bukanlah sembuh atau tidak sembuhnya pasien (resultaat verbintenis) (Rozi Oktri Novika, 2015 : 2). Dengan demikian seorang dokter gigi beresiko menghadapi adanya gugatan atau tuntutan atas ketidakpuasaan pasien dalam pelayanan kesehatan di Puskesmas yang kurang didukung oleh sumber daya manusia, sarana dan prasarana yang memadai.

\section{Identifikasi Masalah}

Bagaimana perlindungan hukum bagi dokter gigi dalam melakukan pelayanan kesehatan di Puskesmas?

\section{Tujuan Penelitian}

Untuk mengetahui perlindungan hukum bagi dokter gigi dalam melakukan pelayanan kesehatan terhadap pasien di Puskesmas.

\section{Metode Penelitian}

Penelitian ini merupakan suatu penelitian yuridis normatif yang bersifat deskriptif analisis, karena penelitian ini berbasis pada analisis norma hukum. Oleh karena penelitian ini merupakan penelitian yuridis normatif, maka sumber datanya adalah berupa data sekunder berupa bahan- bahan hukum, yang dilakukan melalui studi dokumen terhadap data sekunder yang diperoleh dengan menggunakan metode penelitian kepustakaan dan studi lapangan. Keseluruhan data sekunder yang diperoleh diolah dan dianalisis dengan menggunakan pendekatan kualitatif dengan menghubungkan ketentuanketentuan hukum yang berlaku tentang perlindungan hukum bagi dokter gigi dalam melakukan pelayanan kesehatan di Puskesmas.

B. HASIL DAN PEMBAHASAN

Perlindungan Hukum Bagi Dokter Gigi Dalam Melakukan Pelayanan

Kesehatan Terhadap Pasien Di
Puskesmas

Perlindungan hukum merupakan suatu hal yang melindungi subyek-subyek hukum melalui peraturan perundangundangan yang berlaku dan dipaksakan pelaksanaannya dengan suatu sanksi. Perlindungan hukum dapat dibedakan menjadi dua, yaitu : (Muchsin, 2003 : 20)

a. Perlindungan Hukum Preventif

Perlindungan yang diberikan oleh pemerintah dengan tujuan untuk mencegah sebelum terjadinya pelanggaran. Hal ini terdapat dalam peraturan perundang- undangan dengan maksud untuk mencegah suatu pelanggaran serta memberikan rambu- 
rambu atau batasan-batasan dalam melakukan suatu kewajiban.

b. Perlindungan Hukum Represif

Perlindungan hukum represif merupakan perlindungan akhir berupa sanksi seperti denda, penjara, dan hukuman tambahan yang diberikan apabila sudah terjadi sengketa atau telah dilakukan suatu pelanggaran.

Dalam kaitannya dengan perlindungan hukum bagi dokter gigi dalam memberikan pelayanan kesehatan di Puskesmas, salah satu bentuk perlindungan hukum yang diberikan terhadap dokter gigi yaitu adanya seperangkat aturan atau ketentuan yang mengatur mengenai hal-hal yang dapat melindungi seorang dokter gigi dalam hal terjadinya sengketa atau perselisihan dengan pasien yang merupakan konsumen. Adapun dasar perlindungan tersebut sebagaimana yang telah ditetapkan dalam Undang-Undang Nomor 36 Tahun 2009 tentang Kesehatan, Undang-Undang Nomor 29 Tahun 2004 tentang Praktik Kedokteran, UndangUndang Nomor 36 Tahun 2014 tentang Tenaga Kesehatan, dan Peraturan Menteri Kesehatan Nomor Republik Indonesia 75 Tahun 2014 tentang Puskesmas.

Berdasarkan Pasal 24 ayat (1) dan Pasal 27 ayat (1) Undang-Undang Nomor 36 Tahun 2009 tentang Kesehatan, mengatur bahwa dokter gigi memiliki hak untuk mendapatkan perlindungan hukum dalam melaksanakan tugas sesuai profesinya, dimana perlindungan hukum tersebut merupakan hak setiap dokter gigi yang diberikan sepanjang dalam melaksanakan pelayanan kesehatan telah memenuhi ketentuan kode etik, standar profesi, hak pengguna pelayanan kesehatan, standar pelayanan, dan standar prosedur operasional. Kemudian, tidak jauh berbeda dengan yang diatur dalam undang-undang tersebut, dalam Pasal 50 Undang-Undang Nomor 29 Tahun 2004 tentang Praktik Kedokteran juncto Undang-Undang Nomor 36 Tahun 2014 tentang Tenaga Kesehatan dalam Pasal 66 ayat (1), juga ditegaskan kembali bahwa pada dasarnya dokter gigi mempunyai hak untuk mendapatkan perlindungan hukum sepanjang telah melaksanakan tugas sesuai dengan profesi dan standar prosedur pelayanan operasional.

Pelaksanaan tugas sesuai dengan profesi dan standar pelayanan operasional kembali dipertegas dalam Pasal 17 ayat (1) Peraturan Menteri Kesehatan Nomor Republik Indonesia 75 Tahun 2014 tentang Puskesmas yang mengharuskan bagi setiap tenaga kesehatan di Puskesmas untuk bekerja sesuai dengan standar profesi, standar pelayanan, standar prosedur operasional, etika profesi, menghormati hak pasien, serta mengutamakan kepentingan dan keselamatan pasien dengan memperhatikan keselamatan dan 
kesehatan dirinya dalam bekerja tidak terkecuali dokter gigi di Puskesmas.

Keharusan dokter atau dokter gigi dalam memberikan pelayanan kesehatan sesuai dengan standar-standar diatas lebih ditekankan lagi dengan adanya sanksi bagi dokter atau dokter gigi yang tidak melaksanakan tugasnya sesuai dengan standar-standar yang telah ditetapkan sebagaimana dimaksud dalam Pasal 79 Undang-Undang Nomor 29 Tahun 2004 tentang Praktik Kedokteran dan Pasal 82 Undang-Undang Nomor 36 Tahun 2014 tentang Tenaga Kesehatan.

Dengan demikian, pada dasarnya perlindungan hukum terhadap seorang dokter atau dokter gigi lahir apabila pelaksanaan tugas pelayanan kesehatan yang dilakukan oleh dokter atau dokter gigi telah sesuai dengan standar profesi dan standar operasional yang ada. Sehingga dengan adanya pelaksanaan tugas sesuai dengan standar profesi dan standar pelayanan operasional yang dilakukannya berarti telah dipenuhi kewajibannya sebagaimana yang diamanatkan undang-undang dan berhak atas perlindungan hukum yang diberikan kepadanya.

Standar profesi adalah pedoman yang harus dipergunakan sebagai petunjuk dalam menjalankan profesi secara baik dan benar (Endang Kusuma Astuti, 2009 : 28). Menurut Leenen, tindakan medis disebut lege atis jika tindakan tersebut telah dilakukan sesuai dengan standar profesi dokter, yaitu :

"Suatu tindakan medis seorang dokter, sesuai dengan standar profesi kedokteran jika dilakukan secara teliti sesuai ukuran medis, sebagai seorang dokter yang memiliki kemampuan rata-rata dibandingkan dengan dokter dari kategori keahlian medis yang sama dengan sarana upaya yang memenuhi perbandingan yang wajar (proporsional) dibandingkan dengan tujuan konkret tindakan medis tersebut."

Berdasarkan rumusan diatas, terdapat 5 (lima) unsur standar profesi medik, yaitu (Endang Kusuma Astuti, $2009: 30-31)$ :

1) Tindakan yang teliti, berhati-hati.

2) Sesuai ukuran medis. Ukuran medis ditentukan oleh ilmu pengetahuan medis. Ukuran medis diartikan sebagai suatu cara perbuatan medis tertentu dalam suatu kasus yang konkret menurut suatu ukuran yang didasarkan pada ilmu medis dan pengalaman dalam bidang medis.

3) Sesuai dengan seorang dokter yang memiliki kemampuan rata-rata dibandingkan dengan dokter dari kategori keahlian medis yang sama. 
Ukuran etika, menurut standar tertinggi dari dokter sesuai dengan Pasal 2 Kode Etik Kedokteran Indonesia 1983 yang menyatakan bahwa dokter harus senantiasa melakukan profesinya menurut ukuran yang tertinggi.

4) Dalam situasi dan kondisi yang sama. Dalam situasi yang sama, misalnya di Puskesmas berbeda dengan rumah sakit tipe A.

5) Dengan saran upaya yang memenuhi perbandingan yang wajar dibandingkan dengan tujuan konkret tindakan medis tersebut. Dokter harus selalu membandingkan tujuan tindakan medis dengan risiko tindakan tersebut dan berusaha untuk risiko yang terkecil.

Berdasarkan rumusan standar profesi kedokteran yang diterbitkan oleh Pengurus Besar Ikatan Dokter Indonesia (IDI), standar profesi dibagi menjadi empat bagian, yaitu : (Endang Kusuma Astuti, $2009: 33-34)$

1) Standar Keterampilan

a. Keterampilan kedaruratan medis, yaitu sikap yang diambil seorang dokter dalam menjalankan profesinya dengan sarana yang sesuai dengan standar ditempat prakteknya. Jika tindakan tidak berhasil, penderita perlu dirujuk ke fasilitas kesehatan yang lebih lengkap. b. Keterampilan umum, meliputi penanggulangan terhadap berbagai penyakit yang tercantum dalam kurikulum inti pendidikan dokter Indonesia.

2) Standar Sarana

Meliputi segala sarana yang diperlukan untuk berhasilnya dokter dalam melakukan pelayanan dan tindakan medis yang meliputi sarana medis dan non medis.

3) Standar Perilaku, meliputi :

a) Pasien harus diperlakukan secara manusiawi,

b) Semua pasien diperlakukan sama,

c) Semua keluhan pasien diusahakan agar diperiksa secara menyeluruh,

d) Pada pemeriksaan pertama diusahakan untuk memeriksa secara menyeluruh,

e) Pada pemeriksaan ulangan diperiksa menurut indikasinya,

f) Penentuan uang jasa dokter diusahakan agar tidak memberatkan pasien,

g) Dalam ruang praktik tidak boleh ditulis tarif dokter,

h) Untuk pemeriksaan wanita agar ada saksi baik dari pihak keluarga atau perawat, kecuali dokternya wanita,

i) Dokter tidak boleh melakukan perzinaan dalam ruang praktek, abortus, kecanduan, dan alkoholisme, 
j) Papan nama terpasang dalam ukuran yang pantas.

4) Standar Catatan Medis

Pada semua penderita, sebaiknya dibuatkan catatan medis yang dicantumkan didalamnya identitas penderita, nama penderita, anamnesis, pemeriksaan, diagnosis, terapi, dan obat yang menimbulkan alergi pada pasien.

Seorang dokter yang menyimpang dari Standar Profesi Medik dikatakan telah melakukan suatu kelalaian atau kesalahan dan dalam hal tersebut dapat merupakan salah satu unsur dari malpraktik medik, yakni apabila kesalahan tersebut bersifat sengaja (dolus) dan menimbulkan kerugian pasien. Standar Profesi Medik merupakan salah satu persyaratan penghapusan tuntutan atau gugatan dikemudian hari kepada dokter. Sehingga bila dokter tidak menyimpangi standar profesi medik dalam pelaksanaan pelayanan medis yang dilakukannya, maka ia tidak dapat dipidana ataupun membayar kerugian (Chrisdiono M. Achadiat, 2007 : 13-15)

Selanjutnya, standar prosedur operasional merupakan suatu rangkaian instruksi atau pedoman tertulis dalam menjalankan suatu tindakan medis yang dilakukan dokter gigi untuk memastikan bahwa suatu tindakan yang diambil atau dilakukan telah mengikuti prosedurprosedur yang telah ditetapkan di tempat ia bekerja sehingga mendapatkan hasil yang sesuai dengan harapan. Pada umumnya suatu standar prosedur operasional berisikan suatu perintah atau ketentuan yang harus senantiasa diikuti atau dijalankan oleh seorang dokter dalam melakukan suatu tindakan medis. Standar operasional prosedur tersebut dibuat dan ditetapkan sesuai dengan standar operasional prosedur minimal yang diamanatkan undang-undang yang telah disesuaikan pada institusi terkait dan ditetapkan oleh pihak yang berwenang menjadi standar prosedur operasional pada institusi tersebut. Sehingga pada dasarnya standar prosedur yang ada di suatu Puskemas belum tentu sama dengan yang ada di Puskesmas lainnya. Dengan demikian seorang dokter gigi pada dasarnya terikat untuk menjalankan standar operasional prosedur pada institusi dimana seorang dokter gigi bekerja untuk dapat memberikan pelayanan kesehatan yang maksimal dan berkualitas.

Pada umumnya standar profesi dan standar prosedur operasional yang wajib diterapkan dokter gigi dalam melakukan pelayanan kesehatan di Puskesmas salah satunya ialah adanya kewajiban atas informed consent dan rekam medik. Informed consent diartikan sebagai suatu persetujuan dari pasien atas tindakan medis yang dilakukan dokter gigi yang dilakukan berdasarkan catatan atau riwayat 
kesehatan pasien yang bersangkutan (rekam medik) (Syahrul Machmud, 2008 : 85) . Dalam hal ini dokter gigi harus menerangkan secara terbuka dan jujur terkait informasi-informasi mengenai diri pasien dan resiko-resiko yang mungkin timbul akibat tindakan medis yang akan dilakukan oleh dokter gigi sebagaimana juga merupakan hak pasien selaku konsumen jasa pelayanan kesehatan.

Dalam hubungan hukum yang lahir antara dokter gigi dan pasien, pada dasarnya lahir karena adanya perjanjian diantara kedua belah pihak yang dikenal dengan perjanjian atau transaksi terapeutik. Yaitu suatu perjanjian atau kontrak dimana seorang dokter berjanji untuk melakukan upaya semaksimal mungkin dalam memberikan pelayanan kesehatan kepada seorang pasien (Salim HS, 2006 ; 45).

Perjanjian terapeutik atau transaksi terapeutik termasuk dalam ispaning verbintenis atau perjanian upaya, karena dokter tidak mungkin menjanjikan kesembuhan kepada pasien, yang dilakukan dokter adalah melakukan pelayanan kesehatan sebagai upaya untuk menyembuhkan pasien. Dalam melakukan upaya ini, dokter harus melakukan dengan penuh kesungguhan, dengan mengarahkan seluruh kemampuan dan keterampilan yang dimilikinya dengan berpedoman kepada standar profesi. Sementara itu, pasien sebagai pihak lainnya yang menerima pelayanan medis menjelaskan dengan sejujurnya tentang riwayat penyakit yang pernah dideritanya serta obat-obatan yang pernah digunakannya selama sakit atau memberikan informasi sebenar-benarnya tentang keadaaan kesehatan dirinya serta harus juga berdaya upaya maksimal untuk mewujudkan kesembuhan dirinya sebagai hal yang diperjanjikan sebagaimana dimaksud dalam Pasal 53 Undang-Undang Nomor 29 Tahun 2004 tentang Praktik Kedokteran. Tanpa bantuan pasien, maka upaya dokter tidak akan mencapai hasil yang diharapakan.

Pada dasarnya suatu perjanjian terapeutik juga merupakan suatu perjanjian pada umumnya yang diatur dalam Buku III KUHPerdata. Sebagaimana perjanjian pada umumnya maka suatu perjanjian terapeutik juga harus tunduk pada ketentuan yang diatur dalam KUHPerdata tentang perjanjian (Bayu Wijanarko, 2014 : 5-6). Suatu perjanjian apapun bentuknya harus mengikuti kaedah-kaedah umum yang berlaku, untuk syarat sahnya suatu perjanjian. Yaitu harus dipenuhi syaratsyarat yang termuat dalam Pasal 1320 KUHPerdata, yaitu adanya kata sepakat diantara para pihak, kecakapan para pihak dalam hukum, suatu hal tertentu dan kausa yang halal (R. Subekti, 2005 : 29-30) 
Didalam transaksi terapeutik, penerima layanan medis terdiri dari pasien orang dewasa yang cakap untuk bertindak, orang dewasa yang tidak cakap sehingga memerlukan persetujuan dari pengampunya dan anak dibawah umur yang memerlukan persetujuan dari orang tuanya. Untuk hal tertentu dalam hal ini adalah suatu upaya penyembuhan yang dalam pelaksanaannya memerlukan kerjasama yang berdasarkan sikap saling jujur dan percaya. Oleh karena itu dalam mengemban kepercayaan ini dokter dalam mengupayakan penyembuhan terhadap pasiennya harus berdasarkan standar medis yang tertinggi. Sedangkan yang dimaksud oleh causa atau sebab yang halal adalah pelayanan kesehatan yang dilakukan tidak dilarang oleh undang-undang, tidak bertentangan dengan kesusilaan dan ketertiban umum.

Pada dasarnya asas yang dianut dalam KUHPerdata menganut asas konsensualisme, artinya suatu perjanjian dianggap telah terjadi ketika ada kata sepakat diantara para pihak dalam perjanjian (Johannes Gunawan, 2003 : 48). Sebagaimana telah dijelaskan diatas bahwa pada dasarnya dokter gigi mempunyai kewajiban atas informed consent sebelum melakukan suatu tindakan medis. Jika dihubungkan dengan asas konsensualisme yang diatur dalam KUHPerdata, dapat dikatakan bahwa kesepakatan suatu perjanjian terapeutik diantara dokter gigi dan pasien di Puskesmas terjadi ketika adanya persetujuan dari seorang pasien (informed consent) atas tindakan medis yang akan dilakukan oleh dokter gigi kepadanya dengan pertimbangan rekam medik atau catatan kesehatan pasien tersebut.

Dalam hukum perjanjian, persejutuan atau kata sepakat yang melahirkan suatu perjanjian harus dilakukan oleh orang yang dianggap cakap melakukan perbuatan hukum dalam hal ini yaitu telah berusia 21 (dua puluh satu) tahun sebagaimana dimaksud dalam Pasal 330 KUHPerdata. Dalam hal pasien bukan termasuk orang yang cakap melakukan perbuatan hukum maka persetujuan atau informed consent atas tindakan medis yang akan dilakukan oleh dokter gigi dapat dilakukan oleh orang tua atau wali dari si pasien tersebut. Dengan demikian maka perjanjian terapeutik telah memenuhi asas konsensualisme dan dianggap telah terjadi hubungan hukum antara pasien dan dokter gigi yang didasarkan atas perjanjian terapeutik.

Persetujuan tindakan medis yang dilakukan oleh pasien atau keluarganya (informed consent), bukan berarti membebaskan dokter gigi atau Puskesmas dari tanggung jawab atas resiko atau ganti kerugian sebagai akibat dari tindakan medis yang dilakukannya. Persetujuan ini 
sangat penting terutama terhadap penanganan yang mengandung resiko medis. Yang dikategorikan dengan resiko medis, yaitu dokter telah melakukan tugasnya sesuai dengan standar profesi atau standar prosedur operasional (SOP) dan/atau standar pelayanan medik yang baik sebagaimana di amanatkan oleh undang-undang. Untuk kategori resiko medis ini, dokter tidak bisa langsung disalahkan karena apa yang dilakukan sudah sesuai dengan standar profesi dan standar prosedur operasional yang ada dan tindakan medis yang dilakukan oleh dokter gigi telah dijelaskan secara keseluruhan berikut dengan resiko yang ada dan pasien telah menyetujuinya.

Akan tetapi, dalam hal timbul kerugian yang dialami pasien atas tindakan medis yang dilakukan oleh dokter gigi, meskipun dalam pelaksanaan pelayanan kesehatan yang dilakukan seorang dokter gigi telah sesuai sebagaimana dimaksud Pasal 24 ayat (1) dan Pasal 27 ayat (1) Undang-Undang Nomor 36 Tahun 2009 tentang Kesehatan, juga Pasal 50 UndangUndang Nomor 29 Tahun 2004 tentang Praktik Kedoteran juncto Pasal 66 ayat (1) Undang-Undang Nomor 36 Tahun 2014 tentang Tenaga Kesehatan. Pada dasarnya dokter gigi dianggap bertanggung jawab untuk mengganti kerugian terhadap pasien atas kerugian tersebut sebagaimana hal itu merupakan hak pasien yang diatur dalam undang-undang.

Pada hubungan hukum dokter gigi dan pasien dalam suatu transaksi terapeutik, pertanggung jawaban seorang dokter gigi atas kerugian yang dialami pasien didasarkan atas adanya perjanjian atau contractual liability dengan menggunakan tanggung jawab perdata secara langsung (strict liability) dari dokter gigi terhadap kerugian yang dialami pasien atas jasa yang diterimanya. Penerapan tanggung jawab ini didasarkan atas adanya perjanjian terapeutik dimana prestasi yang harus dilakukan oleh seorang dokter dalam transaksi terapeutik tidaklah dapat diukur atau merupakan perjanjian ikhtisar (inspanning verbintenis) (Heru P. Sanusi, 2006 : 66-68)

Dihubungkan dengan sistem pembuktian dalam hal terjadinya kerugian yang di klaim oleh pasien yang didasarkan adanya perjanjian terapeutik (presumption of liability), berdasarkan prinsip tanggung jawab dalam ilmu hukum tersebut bahwa dokter atau dokter gigi dianggap bersalah atas kerugian yang timbul dari perbuatannya sampai ia dapat membuktikan bahwa kerugian yang timbul bukan akibat dari kesalahan atau kelalaian yang dilakukannya (E. Suherman, 2000 : 190) dalam pelayanan kesehatan sebagaimana dimaksud dalam Pasal 58 ayat (1) UU Kesehatan. Adapun dasar- 
dasar peniadaan hukuman seorang dokter atau dokter gigi atas kerugian yang dialami pasien adalah resiko dalam pengobatan, kecelakaan, kekeliruan dalam penilaian klinis, volenti non fit iniura dan contributory negligence (Danny Wiradharma, 2002 : 107)

Dengan demikian pelaksanaan tugas dokter gigi sesuai dengan standar profesi dan standar prosedur operasional yang didukung dengan adanya informed consent dan rekam medik sangat penting dalam memberikan perlindungan hukum bagi dokter gigi. Oleh karena hal tersebut merupakan kewajiban sebagaimana yang telah ditentukan undang-undang untuk dapat menuntut haknya dalam memperoleh perlindungan hukum apabila terjadi perselisihan atau sengketa dikemudian hari atau menghadapi adanya tuntutan dari pasien atas tindakan medis yang dilakukan oleh dokter gigi dalam hal pemberian layanan kesehatan di sarana kesehatan Puskesmas. Dimana kewajiban-kewajiban tersebut juga dipaksakan dengan adanya sanksi bagi dokter gigi tidak melaksanakan tugasnya sesuai dengan standar yang telah ditetapkan oleh undang-undang.

\section{PENUTUP}

Perlindungan hukum bagi dokter gigi dalam melakukan pelayanan kesehatan terhadap pasien di Puskesmas merupakan hak yang diberikan oleh hukum sepanjang telah melakukan tugasnya sesuai dengan standar profesi dan standar prosedur operasional sebagaimana yang diatur dalam Undang-Undang Nomor 36 Tahun 2009 tentang Kesehatan, Undang-Undang Nomor 29 Tahun 2004 tentang Praktik Kedokteran, Undang-Undang Nomor 36 Tahun 2014 tentang Tenaga Kesehatan, dan Peraturan Menteri Kesehatan Nomor Republik Indonesia 75 Tahun 2014 tentang Puskesmas. Standar profesi dan standar prosedur operasional yang wajib diterapkan dokter gigi dalam melakukan pelayanan kesehatan di Puskesmas diantaranya yaitu kewajiban atas informed consent dan rekam medik dalam melakukan suatu tindakan medis.

\section{Daftar Pustaka}

Agus Budianto, at., al., Aspek Jasa Pelayanan Kesehatan Dalam Perspektif Perlindungan Pasien, Karya Putra Darwati, Bandung, 2010 .

Bayu Wijanarko, Mudiana Permata Sari, Tinjauan Yuridis Sahnya Perjanjian Terapeutik dan Perlindungan Hukum Bagi Pasien, Jurnal Private Law, Universitas Sebelas Maret, Surakarta, 2014.

Chrisdiono M. Achadiat, Dinamika Etika dan Hukum Kedokteran, EGC, Jakarta, 2007.

Danny Wiradharma, Penuntun Kuliah Hukum Kedokteran, Cet.I, Bina Rupa Aksara, Jakarta, 2002. 
E. Suherman, Aneka Masalah Hukum Kedirgantaraan, Mandar Maju, Bandung, 2000.

Endang Kusuma Astuti, Transaksi Terapeutik Dalam Upaya Pelayanan Medis di Rumah Sakit, PT. Citra Aditya Bakti, Bandung, 2009.

Hadi Mahmud, Suparwi, Perlindungan Hukum Terhadap Pelayanan Pasien Di Puskesmas Kecamatan Jaten Kabupaten Karanganyar, Jurnal Serambi Hukum Vol. 08 No. 02, Surakarta, Agustus 2014- Januari 2015.

Heru P. Sanusi, at., al., Diktat Hukum Dagang, Fakultas Hukum Universitas Trisakti, Jakarta, 2006.

Johannes Gunawan, Reorientasi Hukum Kontrak di Indonesia, Jurnal Hukum Bisnis Vol. 22 No. 6, 2003.

Kitab Undang-Undang Hukum Perdata.

Mariane Sembel, Henry Opod, Bernart S. P. Hutagalung, Gambaran Kepuasan Pasien terhadap Perawatan gigi dan Mulut di Puskesmas Bahu, Jurnal eGigi (eG), Volume 2, Nomor 2, Manado, Juli-Desember 2014.

Muchsin, Perlindungan dan Kepastian Hukum Bagi Investor di Indonesia, Magister Ilmu Hukum Program
Pascasarjana Universitas Sebelas Maret, Surakarta, 2003.

Peraturan Menteri Kesehatan Nomor Republik Indonesia 75 Tahun 2014 tentang Pusat Kesehatan Masyarakat.

R. Subekti, Hukum Perjanjian, Cet. 21., Intermasa, Jakarta, 2005.

Rozi Oktri Novika, Kedudukan Hukum Perjanjian Terapeutik (Antara Rumah Sakit Dan Pasien) Dalam Persetujuan Tindakan Medik Menurut Kitab Undang-Undang Hukum Perdata, JOM Fakultas Hukum Volume 2 Nomor 1 Februari 2015.

Salim H.S., Hukum Kontrak : Teori \& Tehnik Penyusunan Kontrak, Sinar Grafika, Jakarta, 2006.

Syahrul Machmud, Penegakan Hukum dan Perlindungan Hukum Bagi Dokter Yang Diduga Melakukan Medikal Malpraktek, CV. Mandar Maju, Bandung, 2008.

Undang-Undang Nomor 29 Tahun 2004 tentang Praktik Kedokteran.

Undang-Undang Nomor 36 Tahun 2009 tentang Kesehatan.

Undang-Undang Nomor 36 Tahun 2014 tentang Tenaga Kesehatan. 